\title{
Drafting CANAdian OILFIELd MASTER SERVICE AgREEMENTS: AN OVERVIEW OF KEY ClAUSES AND MARKET TRENDS
}

\author{
Trent Mercier, Josh Kane, And SharbiL NAMmour*
}

A cohesive master service agreement is a fundamental component of the operator-service provider relationship for the provision of oilfield services for upstream oil and gas operations. This article: explores the sometimes unique contract relationships found in the Canadian marketplace; provides an overview of key contentious issues and potential solutions, which are examined and contrasted with those seen in American and international contracts; and identifies recent relevant market trends, including special considerations for large-scale hydraulic fracturing operations and the perspectives of new international operators entering the Canadian marketplace.
Le contrat général de prestation de services représente un élément fondamental de la relation l'exploitant et le fournisseur de service pour la prestation de services nécessaires à la production pétrolière et gazière en amont. Cet article explore la relation contractuelle parfois unique qui existe sur le marché canadien; il donne un aperçu des grandes questions litigieuses et des solutions envisageables qui sont examinées et comparées à ce que l'on retrouve dans les contrats américains et internationaux; et il identifie les dernières tendances de marché pertinentes, incluant les considérations spéciales pour les opérations de fracturation hydraulique à grande échelle et les perspectives de nouveaux exploitants internationaux entrant sur le marché canadien.

\section{TABLE OF CONTENTS}

I. INTRODUCTION . . . . . . . . . . . . . . . . . . . . . . . . . . 246

II. Model Agreements . . . . . . . . . . . . . . . . . . . . . . . . . . . . . . 247

III. Negotiating the Master Service AgreEMENT $\ldots \ldots \ldots \ldots \ldots \ldots 248$

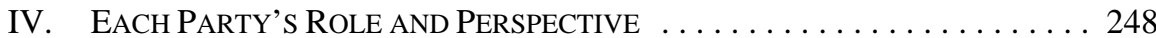

A. PRICING FOR RISK . . . . . . . . . . . . . . . . . . . . . . 248

B. Control of the Operations $\ldots \ldots \ldots \ldots \ldots \ldots \ldots \ldots . \ldots 249$

V. LIABILITY AND INDEMNIFICATION REGIMES $\ldots \ldots \ldots \ldots \ldots \ldots \ldots . \ldots \ldots$

A. Fault-Based Regimes $\ldots \ldots \ldots \ldots \ldots \ldots \ldots \ldots \ldots \ldots \ldots \ldots \ldots$

B. Mutual Hold HaRMLess (KNOCK-FOR-KNOCK) . . . . . . . . . 254

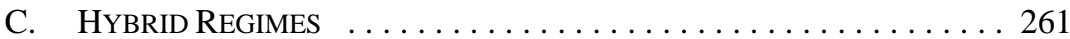

VI. WARRANTY AND REMEDY ISSUES $\ldots \ldots \ldots \ldots \ldots \ldots \ldots \ldots \ldots \ldots \ldots 262$

A. IMPLIED WARRANTIES AND SALE OF GOODS ACT . . . . . . . . . 262

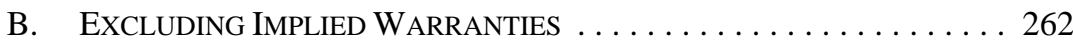

C. WARRANTY PERIOD . . . . . . . . . . . . . . . . . . . . . . . . . 264

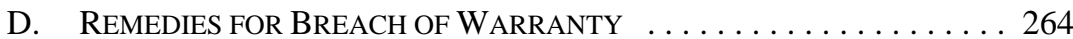

VII. CONSEQUENTIAL LOSS EXCLUSIONS $\ldots \ldots \ldots \ldots \ldots \ldots \ldots \ldots \ldots$

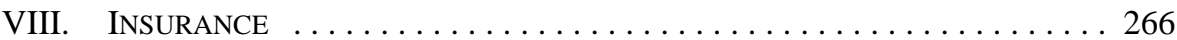

A. TyPicAl InSURANCE Policies $\ldots \ldots \ldots \ldots \ldots \ldots \ldots \ldots$

B. ENDORSEMENTS TO CONTRACTOR'S INSURANCE . . . . . . . . . . 268

C. Protecting the Insurance Bennefits $\ldots \ldots \ldots \ldots \ldots \ldots . \ldots 273$

D. SubCONTRACTORS . . . . . . . . . . . . . . . . . . . . . . . . . . 274

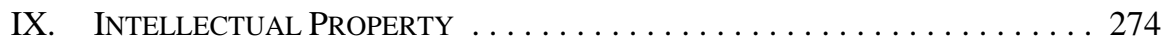

A. Issues With IP PROVISIONS $\ldots \ldots \ldots \ldots \ldots \ldots \ldots \ldots \ldots \ldots \ldots$

Trent Mercier is a senior Associate at Norton Rose Fulbright Canada LLP. Josh Kane is Corporate Legal Counsel (Canada) at Sanjel Corporation. Sharbil Nammour is Account Manager at Jones Brown Inc. This article discusses the views of the authors and not necessarily the views of their companies, firms, or clients. 
X. Compliance with Human Resources and HSE Policies . . . . . . . . 277

XI. Required HoldBACK UNDER the BUILDERS' Lien ACT . . . . . . . . . . . 277

XII. CANADIAN JURISPRUDENCE . . . . . . . . . . . . . . . . . . . . . . . . . . . . . 278

A. HORIZON RESOURCE MANAGEMENT LTD.

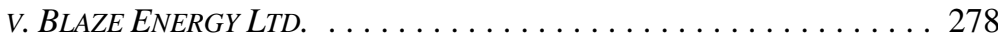

B. BRINKERHOFF INTERNATIONAL INC.

V. NUMAC ENERGY INC. . . . . . . . . . . . . . . . 279

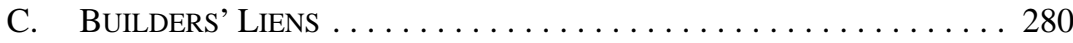

XiII. Caution When Using Model Agreements $\ldots \ldots \ldots \ldots \ldots . \ldots . \ldots . . \ldots 28$

XIV. RECENT TRENDS AND OPEN IsSUES $\ldots \ldots \ldots \ldots \ldots \ldots \ldots \ldots \ldots \ldots . \ldots \ldots$

A. Contractor Liability for Subsurface Pollution . . . . . . 283

B. CONTRACTORS MODIFYING KNOCK-FOR-KNOCK

INDEMNITIES IN REgARDS TO PRESSURE PUMPING SERVICES $\ldots \ldots 283$

C. DOES A BREACH OF Duty OF CARE

INVALIDATE THE INDEMNITIES? . . . . . . . . . . . . . . . . . . . . 283

\section{INTRODUCTION}

The Canadian upstream oil and gas industry, much like the broader international oil and gas industry, is broadly organized into two categories. Those companies specializing in exploring for and producing oil and gas (the Operators), and those companies that specialize in providing the services necessary to support and facilitate the exploration and developing activities (the Contractors). The procurement and delivery of services under this structure necessitates a huge number of contracts. In order to reduce the number of contracts and the amount of time involved to negotiate them, the industry has broadly adopted an approach whereby an umbrella agreement is entered into between an Operator and a Contractor that establishes the general terms and conditions that will govern the procurement and delivery of services which the Operator may call upon the Contractor to provide from time to time. This agreement is commonly referred to as a master services agreement, a service agreement, or general terms and conditions. This article will refer to these types of agreements generically as MSAs.

The objective of this article is to provide a practical reference tool to assist in the negotiation of MSAs for oil and gas well services (for example, well cementing, well pressure testing, well stimulation services, nitrogen services, coil tubing services, underbalanced drilling, and so on). The article is organized around the following areas: (1) identifying the key issues that frequently are the subject of negotiation of an MSA; (2) describing the various approaches that have developed to address each of these issues; (3) discussing the risks to be aware of in regards to each of these approaches (namely the impact on the risk allocation between the parties); and (4) highlighting recent trends and upcoming issues to be aware of.

While the focus of this article is on MSAs for well services, many of the issues addressed herein will also be relevant to other types of oilfield services, including drilling services, seismic services, and field consulting services (although there are additional unique issues that arise in respect of each of those services). Also, while the article focuses on the Canadian industry, noteworthy international trends are identified. These trends are increasingly being adopted by the Canadian industry as a result of a broader spectrum of 
Canadian companies gaining international experience and because of the increased presence of internationally-controlled operating companies in Canada.

\section{Model Agreements}

To increase the efficiency of the MSA negotiating process, attempts have been made by the Canadian industry to adopt a model form MSA. This reflects a broader trend both in the Canadian and the international upstream oil and gas sector to standardize agreements.

A model form drilling services agreement and a model form work-over services agreement have been widely adopted in Canada. However, the model form MSA for well services has not been widely adopted by the Canadian industry. This is despite the Petroleum Services Association of Canada (PSAC) — the industry group representing Canadian well services providers - publishing a model form MSA; ${ }^{1}$ and the Canadian Association of Oilwell Drilling Contractors (CAODC) and the Canadian Association of Petroleum Producers (CAPP) also co-publishing their model form MSA. ${ }^{2}$ There is a high degree of similarity between the PSAC Model and the CAPP/CAODC Model. Considering that the industry groups publishing these forms represent Operators and Contractors, it is surprising that those model forms have not been widely accepted.

In the international context, the Association of International Petroleum Negotiators (AIPN) and the Petroleum Equipment Suppliers Association (PESA) jointly developed an MSA for well services. ${ }^{3}$ It has achieved partial acceptance in the United States marketplace, but company-based forms remain the dominant basis for MSAs. The International Association of Drilling Contracts (IADC) has also established a model form MSA for drilling services and well services. IADC is the international equivalent of the CAODC. However, the well services MSA has not achieved broad industry acceptance. Outside of the onshore US, the IADC drilling contracts are primarily used as a reference tool rather than adopted as a model form. The United Kingdom offshore oil and gas industry has established an MSA. This is the second edition of the "General Conditions of Contract (including Guidance Notes) for Services (On- and Off-Shore)," which is published by LOGIC. ${ }^{4}$ LOGIC has also established a model form drilling contract. Both LOGIC models have achieved broad acceptance in the UK North Sea, and they serve as valuable reference tools in the broader international context. ${ }^{5}$

Petroleum Services Association of Canada, “PSAC Master Service Agreement, December 2005,” online: PSAC < www.psac.ca/wp-content/uploads/msa.pdf> [PSAC Model].

2 Canadian Association of Oilwell Drilling Contractors \& Canadian Association of Petroleum Produces, “CAPP CAODC Master Well Service Contract, November 2003,” online: CAPP < www.capp.ca/getdoc. aspx?DocId=149146\&DT=NTV $>$ [CAPP/CAODC Model $]$.

3 AIPN is an international organization with broad representation of stakeholders in the international oil and gas industry. PESA is the United States-based organization representing well services providers. Association of International Petroleum Negotiators \& Petroleum Equipment Suppliers Association, “2002 International Model Well Services Contract,” online: Rocky Mountain Mineral Law Foundation $<$ www.rmmlf.org/Istanbul/8-International-Model-Well-Services-Contract.pdf> [AIPN/PESA Model].

4 LOGIC, "Standard Contracts for the UK Offshore Oil \& Gas Industry: General Conditions of Contract (including Guidance Note) for Services (On- and Off-Shore),” 2d ed (October 2003), online: LOGIC $<$ www.logic-oil.com/sites/default/files/documents/Services\%20Onshore\%20and\%20Offshore\%20 Edition\%202.pdf> [LOGIC Model].

LOGIC, "General Conditions of Contract for Mobile Drilling Rigs: Guidance Notes,” 1st ed ( December 1997), online: LOGIC < www.logic-oil.com/sites/default/files/documents/Mobile\%20Drilling\%20Rigs \%20Guidance\%20Notes.pdf $>$. 


\section{Negotiating the Master Service Agreement}

Due to the lack of widespread acceptance of an industry standard MSA, there remains a wide variety of forms of MSAs for well services. Many Operators and Contractors have their own forms, which reflect their particular experiences and preferences. As a result, finalizing an MSA for well services continues to require a considerable amount of negotiation. While the result of these negotiations will be heavily dependent upon the relative negotiation leverage of each party, it is critical for negotiators to be aware of the key issues arising and the impact of each issue to the risk allocation between the parties. For each of the main topics, a variety of approaches have developed and special care must be taken in selecting an approach so as to ensure that the desired risk allocation is achieved.

In essence, the MSA is a risk allocation tool. Consequently, considerable focus will be dedicated to the liabilities and indemnities. However, as will be explored in this article, various other terms commonly found in an MSA can have a significant impact on the risk allocation between the parties. Some of these effects are subtle but, nonetheless, can result in important deviations from the risk allocation established in the liability and indemnity provisions.

While it is always important for parties to appreciate fully the risk allocation achieved in the agreement, this is of particular importance for Contractors providing well services that are currently in a low point in the pricing cycle. If work is going to be performed with little or no profit margin (in order to protect market share), the risk that is assumed in performing this work ought to be carefully managed. ${ }^{6}$

\section{EACH PARTY’s Role AND PERSPECTIVE}

A good place to start discussing the critical issues for an MSA is with the main motivators of each party to the agreement. While this may seem like a prosaic matter to address, it is the experience of the authors that negotiations are frequently more challenging than ought to be the case due to negotiators losing sight of these motivators.

Generally speaking, the Operator wants to ensure that the service is done in a timely, safe, and cost-effective manner that satisfies the relevant operational objectives. On the other hand, the Contractor wants to achieve a rate of return for performance of the services which is reasonable in the context of (1) the specialization of the services involved, (2) the cost of equipment, and (3) and the riskiness of the operation. Neither party wants to take on a degree of risk that is impracticable and counterproductive.

\section{A. PRICING FOR RISK}

An Operator's risk can best be minimized by selecting a Contractor who has skill and experience in the services that are the subject of the MSA, and who has a good operating track record. Having the most favourable risk allocation regime in the MSA is a poor substitute for a first-class Contractor. 
Contractors frequently argue that their upside is fixed and relatively small compared to the investment, whereas Operators have the potential for a significant upside benefit as compared to their investment. The counterpoint is that the assumption of risk by the Contractor is a powerful incentive for the Contractor to perform the services to the standards the Contractor covenanted in the MSA.

Operators expend significant sums of money on insurance coverage (as further discussed below in Part VIII). However, Operators frequently request the Contractor to assume onerous risk allocation. The Operator's rationale is that if the requested risk allocations are accepted by the Contractor, then the Operator's insurance will not need to be drawn up. The counterpoint, however, is that a prudent Contractor may increase its rates so as to adjust for the increased risk, which could result in a fixed commercial cost to the Operator that outweighs the practical likelihood of the risk event occurring and costs to the Operator if the event does occur. Another outcome is that the Contractor accepts the risk even though it may not have insurance coverage for the risk event, and thus the Operator has paid a premium price for risk protection from which it may not benefit.

Hence, if the risk that the Contractor is being asked to take on is within the Contractor's control, it is challenging to justify why the Contractor should not assume the risk. The corollary is that if the risk is outside of the control of the Contractor, or is within the greater control of the Operator, then this risk is more appropriately placed with the Operator.

\section{B. CONTROL OF THE OPERATIONS}

Contractors frequently comment that the Operator, as the representative of the owners of the well, is the party most familiar with the well and, ultimately, is in control of the operation. Therefore, the Operator should hold the balance of the risk. Conversely, from the Operators' perspective, they hire a Contractor because of its purported expertise in relation to the contracted service, and thus the Operator is dependent upon the Contractor to ensure that the services are performed correctly. These competing perspectives became part of the public dispute between BP and Halliburton in connection with responsibility for the blowout of the BP-operated Macondo well in the Gulf of Mexico in 2010 (the Macondo blowout). Halliburton provided cementing services for the well and accused BP of using fewer casing centralizers than Halliburton recommended, whereas BP accused Halliburton of performing the cementing services poorly. ${ }^{7}$

\section{CONTRACTORS' StANDARD OF PERFORMANCE}

It is now a generally accepted practice for MSAs not to include a warranty of "fit for purpose" or warrant the results of the service. However, a warranty, such as "Contractor represents that the equipment and goods it will provide are suitable to provide the services," appears from time to time in Operator-orientated MSAs. While this warranty appears to be

Specifically, six centralizers were used to stabilize the well bore during cementing. Halliburton claimed that 21 centralizers should have been used. While this dispute is ongoing, Halliburton has pleaded guilty to destroying evidence of internal tests it conducted showing there was no difference between the effectiveness of putting six or twenty-one centralizers in the well. See Nick Snow, "Halliburton unit admits destroying Macondo incident evidence” Oil \& Gas Journal (26 July 2013), online: <www.ogj. com/articles/2013/07/halliburton-unit-admits-it-destroyed-macondo-accident-evidence.html>. 
benign, a Contractor needs to be cautious. As far as the authors are aware, no Canadian court has yet considered the effect of this wording. However, a plain reading would suggest a similar intent as "fit for purpose" and potentially also "guarantee of results."

In most circumstances, this type of wording is overly onerous on the Contractor. The Operator is most familiar with the wellbore and the adjacent geological conditions. It is also the entity that designs the well and prepares the well drilling program. Thus, a fair and balanced level of assurance for the Operator to seek from the Contractor is that (1) the Contractor's equipment and goods comply with the specifications detailed in the service program provided to the Contractor by the Operator and (2) the Contractor will perform the services in conformity with the Operator's specifications identified in the MSA.

The selected approach can have a significant impact on risk allocation, since it is typical for an MSA to include a service warranty, which is triggered by the Contractor not complying with the Contractor assurances. The service warranty is itself a material issue of negotiation and will typically impose significant financial and operational obligations upon the Contractor. This ought to be the case so as to provide proper incentive or disincentive, depending on your perspective, to comply with the performance assurances.

\section{SPECIFICATIONS OF THE OPERATION}

In Operator-orientated MSAs, the Contractor has a duty to notify the Operator of any errors in the specifications or of missing information that the Contractor becomes aware of. Sometimes this wording goes even further and obligates the Contractor to provide any improvements that it may be aware of. Such a clause helps align the parties and achieve the mutual goal of the operation being performed in the best possible manner. However, a Contractor should not accept this duty lightly. A Contractor failing to review the specifications carefully and notify the Operator of defects, missing information, and improvements, if required, would be a breach of such a standard. Such a breach would attract Contractor liability on the basis of breach of contract. While this may be limited by a liability cap, the legal liability can still be significant, let alone the negative effect on reputation. It could also trigger the "service warranty" if the error or missing information prevents the Contractor from performing the services. If a clause such as this is presented, it is recommended that the following concepts be included:

- An express disclaimer of liability for any comments provided by the Contractor. While it is reasonable to expect the Contractor to review the specifications carefully and notify the Operator of errors, missing information, or potential improvements, the purpose of the MSA is for the provision of the well service, not the design of the service. If the Operator desires assistance in the design of the service, then the scope of the services should be expanded to include this work, and specific provisions should be prepared to establish the standard by which this work is to be performed and the consequences for breach of such standard.

- The service warranty should include an exculpatory provision such that the service warranty is not triggered to the extent that the Contractor has reasonably relied on inaccurate or incomplete information supplied by or on behalf of the Operator. This carve-out does not lessen the Contractor's responsibility for reviewing and 
providing comments on the specification, but it does clarify that if there are errors in the specifications and the Contractor does not identify these, despite using reasonable efforts, that it will not become responsible for adverse effects on the performance of the services caused by such errors or missing information.

\section{LiABILITY FOR WELL Site HAZARDS}

Another provision frequently appearing in Operator-orientated MSAs is an acknowledgment by the Contractor that it has had the opportunity to familiarize itself with the location where the services are to be performed. Operators seek this acknowledgement so as to obtain comfort that the Contractor has selected equipment suitable to performing the services in the specific operating conditions. This is a fair and reasonable request. However, additional language is occasionally added whereby the Contractor is required to acknowledge that it is aware of all hazards or potential hazards, or, even more onerous, requires the Contractor to disclaim the Operator from liability for any such hazards. It is difficult to rationalize this additional wording. It causes the Contractor to assume the risk of knowing the condition of the well site, including how it was constructed. This information is beyond what the Contractor can reasonably ascertain. It is the Operator's well site, and it has designed and constructed it. Therefore, the Operator is in the best position to ensure that the well site is safe and properly constructed. The Operator's desire to reduce liability for damage or injury to the personnel or equipment of the Contractor as a result of hazards on the well location can be addressed in the indemnity and liability provisions (as discussed below).

If the Operator's intention for this type of additional wording is to prevent the Contractor from using hazards on the well location as a basis for being relieved of its duty to perform the services safely, this concern can more fairly be addressed through the health, safety, and environment (HSE) standards adopted into the MSA. Namely, this would be achieved by requiring the Contractor to perform the services in compliance with HSE standards that meet or exceed those of the Operator's HSE policies and procedures.

Despite such concerns and alternative solutions, it is the authors' experience that many Operators insist upon the inclusion of broadly worded Contractor acknowledgments for worksite hazards, and that a number of well service Contractors accept these onerous obligations. It is worth noting that drilling Contractors steadfastly refuse to accept such wording. Instead, the model form drilling contracts impose upon the Operator an obligation to represent to the Contractor that the well site is safe and suitable for the equipment. This different approach may be attributed to technical reasons, such as the significant weight of the drilling equipment, the longer duration of the equipment being on the well site, or the high cost of the equipment. However, it is the authors' suspicion that this has more to do with well service Contractors tending to discount potential risks more heavily than their drilling counterparts.

\section{LIABILITY AND INDEMNIFICATION REGIMES}

It is the authors' experience that liability and indemnification regimes seen in the Canadian marketplace can be divided into three general categories: (1) fault-based regimes; (2) mutual hold harmless regimes (knock-for-knock) regimes; and (3) hybrids of these two. 


\section{A. FAult-BASEd Regimes}

These regimes assign liability based on fault. However, instead of relying on common law principles, these regimes typically include express contractual indemnities. Because they are often Operator-drafted contracts, most Canadian MSAs with fault-based regimes start with what is a very broad contractual indemnification in favour of the Operator, and do not contain a reciprocal indemnity in favour of the Contractor.

\section{COMMON IsSUES WITH FAULT-BASED REGIMES}

Fault-based regimes can suffer from drafting that is overreaching. While standard form agreements often try to "cast the widest net" possible, this approach usually leads to an increase in the number of exceptions to be reviewed by the Operator's counsel, and an unnecessary lengthening of the negotiation process as a whole. For example, a fault-based regime might read as follows:

Contractor shall be liable for and shall indemnify and save harmless Operator of and from all manner of actions, causes of action, proceedings, claims, demands, loss, costs, damages, and expenses whatsoever which may be brought or made against Operator, or which it may sustain, pay, or incur, arising out of, related to, or in connection with the performance, purported performance, or non-performance of this agreement or other work hereunder.

A common issue, which is present in the above indemnity, is that the indemnification purports to include claims and expenses "arising out of, related to, or in connection with" the work, rather than simply those claims arising out of a breach of the agreement or the negligent or wilful misconduct of the Contractor-related parties. Thus, as a result of the above indemnity, the Contractor could have the contractual obligation to indemnify the Operator for third party claims where the claims or expenses have no fault connection to the Contractor but are merely "related to, or in connection with" the work. This issue is often seen in conjunction with the statement that the indemnity is in addition to the rights the indemnified party has under common law.

Second, while the above indemnity is often intended by the Operator to include indemnification from its own costs, not just those arising from third parties, this may not be the case if drafted narrowly. However, the Alberta Supreme Court Appellate Division decision in Mobil Oil Canada Ltd. v. Beta Well Service Ltd. ${ }^{8}$ provides a cautionary tale that strict construction and contra proferentem could mean that the indemnity provision only covers losses suffered by the indemnified party as a result of third party claims and not the losses directly suffered by the indemnified party. This is not to say that first-party losses cannot be indemnified, just that the clause must be broad enough to cover losses suffered by the indemnified party. ${ }^{9}$ Thus, if the intention of the parties is to indemnify for first-party losses, it is recommended that the indemnity be drafted to contemplate those losses clearly. ${ }^{10}$ 
A related but less common issue is where the Contractor is asked to indemnify the Operator for any damages related to the work, even when caused by the Operator's own negligence (or sometimes gross negligence). An imbalance in negotiating power between service providers and Operators is what led to a pervasive use of that very risk allocation in the US. In an attempt to solve the problem, statuary protections in the US were implemented that sought to void any such arrangement. Examples of these statutory "anti-indemnity" statutes include the Texas Oilfield Anti-Indemnity Statute (TOAIS) and the Louisiana Oilfield Anti-Indemnity Act (LOAIA). ${ }^{11}$ There are currently no such statutory anti-indemnity provisions in Canada.

\section{MONETARY CAPS}

Where a fault-based regime is used, a Contractor may try to negotiate a monetary cap on its liability. While monetary caps may be accomplished in multiple ways, there are some issues to consider:

(a) Is the amount of the cap reasonably tied to the Contractor's ability to pay?

(b) Is an aggregate cap for all types of liability appropriate, or are there limits applicable to particular indemnity obligations?

(c) Is the monetary cap a per incident or occurrence cap or limited to a certain time period?

(d) Is the monetary cap independent of, or tied to, the value of the service?

a. Is the Amount of the Cap Reasonably

Tied to the Contractor's Ability to Pay?

While it may be a negotiating "win” to have a Contractor agree to a high liability cap, this is only valuable to the Operator if the Contractor has the financial (or insurance) means to make good on its indemnity. Thus, the first step in the Operator's monetary cap analysis should be the financial standing of the Contractor, and whether the amount of the requested monetary cap is reasonably related to the amount of security or insurance (as discussed further below) available to the Operator to ensure the Contractor can backstop its indemnities.

$11 \quad$ For further details on TOAS and LOAIA see Nick Kangles et al, "Risk Allocation Provisions in Energy Industry Agreements: Are We Getting it Right?” (2011) 49:2 Alta L Rev 339 at 341-42; Richard C Beu \& Donald P Butler, "Stress Test for Upstream Contractual Risk Management: Indemnities, Insurance, and Limitation of Liability Clauses After Deepwater Horizon” (Paper delivered at the Rocky Mountain Mineral Law Fifty-Seventh Annual Institute, 21-23 July 2011), (2011) 57 Rocky Mountain Mineral Law Institute 12-1. 
b. Is an Aggregate Cap for All Types of Liability

Appropriate, or are There Limits Applicable to

Particular Indemnity Obligations?

When reviewing the Contractor's proffered monetary cap, the review should be conducted with an eye to the available insurance, as well as the likelihood of each type of claim based on the type of service being performed. For example, is the \$3 million cap applicable to all types of damages or is $\$ 1$ million available for personal injury or death, but $\$ 2$ million available only for damage to property? If the Contractor is a small company and has a \$2 million policy limit for each of its forms of insurance, the additional \$1 million offered in the first example may not ultimately be available for recovery.

c. Is the Monetary Cap a Per Incident or Occurrence

Cap or Limited to a Certain Time Period?

Monetary caps are most commonly given on a "per incident” basis. However, on certain occasions the limit may be time-based (for example, \$2 million per contract year). In such a case, it is important to specify whether or not such a limit is cumulative (for example, \$2 million per contract year for three years, such that at year three there is a $\$ 6$ million aggregate cap).

d. Is the Monetary Cap Independent of, or Tied to, the Value of the Service?

A more recent trend with monetary caps is to tie the cap to the value of the services being performed. For example, instead of a \$3 million per incident cap, the cap is stated as being equal to, or a multiple of, the value of the services provided. This has an advantage should a change in scope of services occur, or if higher-value services are requested from the Contractor in the future.

\section{B. MUTUAL HOLD HARMLESS (KNOCK-FOR-KNOCK)}

The second liability regime found in the Canadian marketplace is based upon mutual hold harmless provisions, also known as a "knock-for-knock" indemnity (KK Indemnity). The KK Indemnity is a broad form indemnity that allocates responsibilities based on control or ownership rather than fault. The Operator and Company agree to indemnify each other against claims and expenses that arise in respect of any damage to property that is owned, hired, or leased and from any injury, illness, or death of its personnel. Key to this regime is that the indemnification obligation applies even where the claims or expenses arise from damage caused by the fault of the other party. As an example:

Contractor's indemnity of Company Group. Regardless of Cause, Contractor Shall Be Liable For And Indemnify Company Group from Claims arising out of personal injury, illness, death, or property loss or damage suffered by any member of Contractor Group. 
Company's indemnity of Contractor Group. Regardless of Cause, Company Shall Be Liable For And Indemnify Contractor Group from Claims arising out of personal injury, illness, death, or property loss or damage suffered by any member of Company Group. ${ }^{12}$

Under a KK Indemnity, the parties then typically allocate risk for specific losses and events (for example, “catastrophic” events), and provide that each party is responsible for the claims of any third party arising from its negligence. It is the experience of the authors that the KK Indemnity regime is the predominant liability regime for service agreements in the US and many international and offshore jurisdictions. Examples of this can be seen in the AIPN/PESA Model ${ }^{13}$ and the LOGIC Model. ${ }^{14}$ The Canadian marketplace, however, has been a slow adopter of the KK Indemnity regime. While the more recent use of the KK Indemnity in the PSAC Model ${ }^{15}$ and CAPP/CAODC Master Well Services Contract ${ }^{16}$ is indicative of a change in the Canadian marketplace to one that is friendlier to the KK Indemnity, Operators in Canada have not yet widely adopted its use.

Proponents of this regime argue that the knock-for-knock system provides for more easily insurable risk, as the extent of indemnity obligations are more clearly known by the party insuring its own people and property. Furthermore, given the complex nature of service operations and what is often a large number of individuals on site, the ability to allocate risk without the need to determine fault can help both the Operator and Contractor avoid a potentially difficult and costly dispute over causation, contributory negligence, and resulting liability.

\section{Allocating SPECIFIC RisKS UNDER A KNOCK-FOR-KNOCK REgIME}

While a knock-for-knock provision allocates liability for persons and property, it is typical to see other risks specifically allocated to either the Operator or the Contractor under these regimes. These include losses due to pollution, blowout, cratering, wild well control, cleanup, well damage, reservoir damage, loss of hydrocarbons, subsurface trespass, and loss of down-hole equipment. Unlike the knock-for-knock, allocation of these risks does not take the form of a mutual hold harmless indemnity and can instead be one-sided. As previously discussed in Part IV above, the main motivators for allocating liability for these specific risks in this manner is based on knowledge or control of the risk, or upon the proportionality of risk to reward. Given that, the Contractor is almost always indemnified from liability for any loss of the reservoir or the hydrocarbons not yet reduced to possession above the surface of the earth. However, indemnification obligations for pollution, subsurface equipment, and the damages caused by well-control incidents are much more variable in their scope.

\section{a. Pollution Liability}

Allocation of liability for pollution is generally at the forefront of the parties' minds when negotiating service agreements. This is especially true in the post-Macondo blowout contracting environment. Because the Operator and Contractor do not necessarily possess

AIPN/PESA Model, supra note 3, ss 13.1.1, 13.1.3 (Alternative 2) [emphasis in original].

Ibid.

Supra note 4, ss 19.1-19.2.

Supra note 1, ss 8.1, 8.7.

Supra note 2, ss 9.1, 9.6. 
the same knowledge, control, and ability to insure for risk related to pollution, it makes sense that allocation of pollution liability is not done with mirrored indemnities. Unlike many jurisdictions where the typical allocation of pollution liability has been somewhat settled, it is the experience of the authors that many of the Operators working in the Western Canadian Sedimentary Basin still try to "push down” as much pollution liability as possible on their Contractors, regardless of whether this ultimately conflicts with their other motivations to lower their service costs and incentivize their Contractors. However, as Contractors often fail to account for contract-specific risk in their pricing models, trying to allocate as much pollution liability to the Contractor may be something that is strategically done by the Operator. Thus, the authors suggest that Contractors maintain communication between their pricing and contracts management groups, so that additional contractual risk can be accounted for in order to maintain reasonable risk-reward ratios.

In the KK Indemnity scenario, Contractors are typically allocated liability based on control. For example, a Contractor is typically responsible for pollution emanating from its equipment while under its control and is required to indemnify the Operator's group from such pollution. However, in the case of drilling contractors, unlike most non-drilling service providers, additional liability may be allocated to the Contractor in the form of a capped indemnity for below-ground damage or pollution (as with the hybrid regimes discussed below). On the other hand, the Operator — who is argued to have better knowledge and awareness of the field, reservoir, structures, and the property as a whole - is generally responsible for all other types of pollution arising from the services. A typical example of allocation of pollution liability with a KK Indemnity can be seen in the PSAC Model as follows:

8.8 Contractor shall assume all the risk of and be solely liable for... pollution or contamination that originates above the surface of the ground from spills of fuels, lubricants, motor oils, wire cuttings, water, paints, solvents and garbage wholly in the possession and control of Contractor's Group and which originates from the Contractor's Group Equipment.

8.9 Operator shall assume all the risk of and be solely liable for... all pollution or contamination not referred to in Section 8.8 including, but not limited to, pollution, radiation damage or contamination that may result from slush pit or Operator's storage tank breakage or seepage, fire, blowout, cratering, or any other uncontrolled flow of oil, gas, water or other substances, as well as from the use or disposition of servicing fluids, disposal, storage or treatment of any dangerous and/or hazardous waste associated with the Services and completion operations, or items of equipment wholly in the possession and control of Operator's Group or directly associated with Operator's Group Equipment. ${ }^{17}$

\section{b. Loss of Down-Hole Equipment}

The clause that is probably the least consistent among service agreements is the indemnity for loss of down-hole equipment. From a Contractor's perspective, the Operator is in the best position to provide information on down-hole conditions and hazards and should be 
responsible for proper preparation of the hole in anticipation of the services. Thus, Contractors often take the position that damage or loss of equipment while down-hole should be the responsibility of the Operator. On the other hand, the Operator does not want to be responsible for damage that resulted from the negligence of the Contractor - whether in its operation or maintenance of the equipment. Nor does the Operator generally wish to provide the Contractor with a windfall of new equipment in the event aging equipment is lost. Consequently, it is common to address the following costs when negotiating indemnification for loss of down-hole equipment:

1) Fishing expenses - who is responsible for the costs? Who arranges the service? How many recovery attempts are included?

2) Equipment costs - how is the cost of repair or replacement set out? Is the reimbursable amount the lower of the repair or replacement cost? Is there a depreciation schedule for the equipment (for example, is refurbishable equipment replaced at new replacement cost)?

Many of the issues and approaches to the loss of down-hole equipment can be seen in the different alternative clauses shown in the AIPN/PESA Model. ${ }^{18}$

c. Catastrophic Losses - Well Control, Blowout, Fire, Explosion, Subsurface Trespass

From the Contractor's perspective, liability for the consequences of what are often referred to as "catastrophic events" (typically well control-related incidents) should rest with the Operator. This is due to the Operator typically being responsible for the design of the well and the well drilling program, the benefits related to the subsurface risk flow to the Operator, and the Operator is generally in a better position to insure against such risks. Conversely, the Contractor may not even be able to insure against certain catastrophic risks such as blowoutrelated property damages.

While many Operator-proposed MSAs contain a catastrophic loss provision, the extent of the indemnity initially proposed in their standard forms vary widely. The clause may provide for a broad indemnity from catastrophic losses, ${ }^{19}$ a more limited indemnity that preserves the knock-for-knock, ${ }^{20}$ or may even be limited to a specific indemnity for only the direct costs of controlling the wild well and removal of debris. ${ }^{21}$ It is therefore critical for the Contractor to understand the extent of the indemnification provided by the Operator for these risks, and measure that indemnity against the insurance it has available to mitigate the resulting risk. 


\section{COMMON ISSUES WITH KNOCK-FOR-KNOCK INDEMNITY REGIMES}

\section{a. Defining the Group}

While the workings of a KK Indemnity are well established, the primary issue of contention arising when negotiating one is the extent of each party's "group.” As the reality of modern well sites is that there can often be numerous contractors and subcontractors on site at any one time, the usefulness of the knock-for-knock regime will be dependent on the extent of the "group" definition. The primary benefit of a broader "group" definition is that the number of potential third party claims, which generally require inquiry into fault, are greatly reduced. From the Operator's perspective, it is typically assumed that any subcontractor of the Contractor would be included in the Contractor's "group” for the purposes of the KK Indemnity. However, the inclusion of the Operator's other contractors in its "group" is subject to considerable disagreement. From the perspective of the Contractor, excluding the Operator's other contractors from the KK Indemnity can fundamentally undermine the value of the knock-for-knock system. This is because the majority of persons and property on site are often those of the Operator's other contractors. Therefore, if such parties and equipment are not included in the Operator's "group," they are third parties, and the Contractor does not enjoy any limitation of liability for damages done to these persons or property — essentially making the KK Indemnity a one-sided release. The reluctance of Operators to extend the KK Indemnity to include their other contractors is often attributed to the administration required to obtain the requisite indemnities from those other contractors, or the presence of pre-existing contractual relationships with those other contractors that do not make use of a KK Indemnity. Of note, the PSAC Model, CAPP/CAODC Model, and the AIPN/PESA Model all include the Operator's other contractors; the LOGIC Model however does not. ${ }^{22}$

\section{b. Priority of the Indemnities}

One of the most often overlooked issues with a KK Indemnity is the priority of the indemnities in the MSA. The most common priority disputes when negotiating an MSA with a knock-for-knock regime are generally as follows:

(i) Does the knock-for-knock take priority?

(ii) Do the specific risk indemnities take priority over the indemnity for third party claims?

(iii) Which of the specific risk indemnities takes precedence?

(iv) Do the specific risk indemnities take priority over more general indemnities that may exist in the MSA? 


\section{i. Does the Knock-for-knock Take Priority?}

In the authors' experience, priority of the catastrophic loss allocation over the knock-forknock component is the second most commonly negotiated term when negotiating a KK Indemnity (second only to inclusion of Operators' other contractors in its “group”). For example, if a blowout causes damage to the Contractor's surface equipment, or back-flowed well effluent causes corrosion to surface equipment that is beyond normal wear and tear, does the KK Indemnity still apply? With regard to the operation of the KK Indemnity in conjunction with the occurrence of a specifically allocated risk, the following options are available:

1) the KK Indemnity takes priority over the specific risk provision;

2) the Operator is required to take responsibility for all personal injuries, deaths, and property damage resulting from the specific risk; or

3) the KK Indemnity does not apply to the extent that the specific risk event occurred as a result of the negligence of the other party (for example, the KK Indemnity would not apply to shield the Contractor from claims for property damage of the Operator group if the Contractor was the sole cause of the blowout).

Regarding the above options, it is the experience of the authors that (1) is by far the most common initial proposal by Operators in Canada, (2) is the regime typically set out in the model agreements, ${ }^{23}$ and (3) is rarely used outside of a hybrid-style indemnification regime (discussed below). Clearly setting out the priority of the risk allocation in a KK Indemnity could have helped avoid the situation experience by the parties in Brinkerhoff International Inc. v. Numac Energy Inc. (discussed in Part XII.B, below). ${ }^{24}$

\section{ii. Do the Specific Risk Indemnities Take Priority}

Over the Indemnity for Third Party Claims?

Another priority issue concerns third party claims. For example, does the indemnity for pollution damages cover third party pollution damages? It is the experience of the authors that typically the specifically allocated risks take priority over the more general third party claims of indemnity. This is also reflected in the various standard form MSA models previously discussed. However, certain Operators have been known to take the position that they will not indemnify the Contractor for claims brought by third parties due to the negligence of the Contractor, regardless of cause.

\section{iii. Which of the Specific Risk Indemnities Takes Precedence?}

Depending on the breadth of the indemnity provided, there can be an overlap between the specific risk indemnities. For example, a blowout indemnity may allocate Operator liability for all claims and damages resulting from a blowout, regardless of the cause, whereas the pollution allocation may state that the Contractor is liable for spills of liquid from its 
equipment, regardless of the cause. In the case where a blowout results in the spills of fracturing chemicals, which provision governs? The solution for resolving this uncertainty is to either clearly set a priority between the specific risk indemnities, ${ }^{25}$ or draft the indemnities specific enough that a conflict or ambiguity is less likely.

\section{iv. Do the Specific Risk Indemnities Take Priority Over}

More General Indemnities That May Exist in the MSA?

As many Operator MSA forms are starting to contain significant representations and warranties related to the performance of the work - and corresponding indemnities for a breach of those representations - it is in the best interests of both parties to set out clearly the priority of the specific risk provisions and their relationship with any other potentially conflicting indemnification obligations. For example, conflicts can occur with indemnities related to the Contractor's breach of its standard of care or a breach of its obligation to perform the work as specified, where re-performance of the services is not the exclusive remedy. ${ }^{26}$ Typically, this conflict is resolved by providing that the specific risk indemnifications apply regardless of any breach of contract or breach of warranty. ${ }^{27}$ It is the experience of the authors that assigning priority to the specific risk provisions is not met with resistance and is advisable in order to avoid uncertainty.

\section{c. Extent of the Indemnities}

While it is typically the goal of an indemnifying party to limit the scope and applicability of any indemnity provided, the reciprocal nature of the KK Indemnity in an MSA is one situation where this goal becomes counterproductive to the intent of the parties. The potential cost consequences to a Contractor that can arise from a catastrophic loss indemnities failing to function as anticipated makes it critical to the usefulness of the MSA's liability provisions to set out the extent of the indemnities. Conversely, Operators should seek to define the extent of the indemnities so as to understand clearly the extent to which they are obligated to indemnify the Contractor group in the event of a catastrophic loss. Key to this clarity for both Operator and Contractor is whether the indemnity applies in the case of the indemnified party’s negligence.

Contract drafters are generally aware that indemnification clauses in Canadian contracts are strictly construed. In the case of a KK Indemnity, one must not only deal with a clause that will be strictly construed, but one that in certain circumstances may result in a party seeking indemnification from the results of its own negligence. It is inherently difficult to contract out of liability for one's own acts of negligence. ${ }^{28}$ In order to do so, and to be indemnified from the results of one's own negligence, there must be very clear terms to that effect. $^{29}$ Both the PSAC Model and CAPP/CAODC Model include language such as "regardless of the negligence or other fault of [Indemnifying Party's] Group." 30 The

See AIPN/PESA Model, supra note 3, s 13.2.10.5 (Alternative 1).

See Part V Liability and Indemnification Regimes, above; Part VI.D Remedies for Breach of Warranty, below.

See Part V.B.2.c Extent of the Indemnities, below.

See Browne v Core Rentals Ltd (1983), 23 BLR 291 at 296 (Ont SC (H Ct J)).

See Canada Steamship Lines Ltd v The King, [1952] AC 192 (PC); Consumers' Gas v Peterborough, [1981] 2 SCR 613; Kangles et al, supra note 11 at 343.

PSAC Model, supra note 1, s 8.2; CAPP/CAODC Model, supra note 2, s 9.5. 
Canadian rule is similar to the "express negligence doctrine" found in various states, such as Texas. ${ }^{31}$ Consequently, one can see another approach to the problem in the AIPN/PESA Model, which addresses the issue by stating that the indemnities apply "Regardless of Cause," 32 which is then defined as follows:

\footnotetext{
"Regardless of Cause" means without regard to Negligence, in whole or in part, of the Party or other Person seeking indemnity or of any other Person. Where expressly stated, Regardless of Cause also means without regard to Gross Negligence, in whole or in part, of the Party or other Person seeking indemnity or of any other Person. ${ }^{33}$
}

Whether a particular MSA goes so far as to seek to have the indemnities apply even in the case of the gross negligence of the indemnified party often depends upon the type of loss being indemnified and the negotiating power of the indemnified party. The AIPN/PESA Model has the inclusion of "Gross Negligence" as an option throughout its various indemnity clauses. ${ }^{34}$ Note, though, that an obligation to indemnify a party in the case of its own gross negligence may be against public policy. ${ }^{35}$ It is also the experience of the authors that Operators are generally unwilling to provide indemnification in the case of the gross negligence of a Contractor. However, blowout-related indemnification is generally an exception to this rule.

Whether the MSA applies its indemnities in the event of gross negligence or, as more often is the case, clearly states that a party is not obligated to indemnify the other in the case of gross negligence, the ideal situation is to set out a definition of gross negligence. Doing so helps the contracting parties to add significant clarity as to the boundaries of their indemnification obligations. ${ }^{36}$

\section{HYBRID REGIMES}

Hybrid liability regimes are the result of any number of combinations of fault-based regimes and knock-for-knock regimes. For example, the knock-for-knock may only apply to the personal injury, illness, or death of each party's personnel, whereas any other liability is addressed on a fault basis up to a set cap. Alternatively, the Contractor may be subject to the typical knock-for-knock liability regime but be asked to assume a specific risk (for example, a risk arising from prior performance issues, such as liability for standby time or damage to the well bore) up to a set dollar value, above which the Operator releases and indemnifies the Contractor. Thus, these regimes can be used effectively to address counterparty specific performance and liability concerns in a MSA.

See Ethyl Corp v Daniel Construction Co, 725 SW (2d) 705 (Sup Ct Tex 1987).

Supra note 3, s 13.

Ibid, s 1.37 .

See e.g. ibid, s 13.2 .5 (Alternative 3).

Kangles et al, supra note 11 at 347.

See generally Miles Pittman, Jaclyn Hesje \& Adam Lamoureux, “Gross Negligence in Canadian Energy Contracts” (2013) 51:2 Alta L Rev 283. 


\section{WARRANTY AND REMEDY ISSUES}

\section{A. IMPLIED WARRANTIES AND SALE OF GOODS ACT}

If the well service provided by a Contractor involves the use of goods (for example, cement, fracking fluid, or acid) the provision of well services may be governed by the applicable provincial sale of goods legislation, such as the Alberta Sale of Goods Act. ${ }^{37}$ In Quebec, similar provisions to the SGA are found in the Civil Code of Québec. ${ }^{38}$ The SGA works to supplement implied terms into the contract of sale where the parties are silent on certain issues or otherwise fail to disclaim those terms. The implied terms include warranties and conditions on the part of the seller (that is, the Contractor), such as: an implied condition that the Contractor has a right to sell the goods; ${ }^{39}$ an implied warranty on the part of the Contractor "that the goods are free from any charge or encumbrance in favour of any third party not declared or known to the buyer before or at the time that the contract is made"; for sales by description, an implied condition that the goods will correspond with the description; ${ }^{41}$ when the buyer "makes known to the seller the particular purpose for which the goods are required so as to show that the buyer relies on the seller's skill or judgment and the goods are of a description that it is in the course of the seller's business to supply ... an implied condition that the goods are reasonably fit for that purpose"; 42 and "[w]hen the goods are bought by description from a seller who deals in goods of that description ... an implied condition that the goods are of a merchantable quality." ${ }^{\text {43 }}$ It is important to note that an express warranty or condition in the contract does not negate a warranty or condition implied by the SGA unless it is inconsistent.

Whether the breach is a breach of warranty or a breach of condition will affect the potential remedy. If there has been breach of a warranty to be fulfilled by the seller, the buyer is not entitled to reject the goods but may reduce or extinguish entirely the price of the good or maintain an action against the seller for damages for the breach of warranty. ${ }^{44}$ If there has been a breach of a condition, the buyer may treat the contract as repudiated, or may elect to treat the breach of the condition as a breach of warranty. ${ }^{45}$ Whether a stipulation in the contract will be treated as a breach of warranty or breach of condition depends in each case on the construction of the contract.

\section{B. EXCLUDING IMPLIED WARRANTIES}

The SGA provides that the parties to a contract for sale of goods may exclude the application of the $S G A{ }^{46}$ This exclusion can be achieved through express language in the contract for sale of goods, by the course of dealing between the parties, or by usage if the usage is such as to bind both parties to the contract. ${ }^{47}$ It is common in MSAs for Contractors

RSA 2000, c S-2 [SGA].

Arts 1708-84 CCQ.

SGA, supra note 37, s 14(a).

Ibid, s 14(c).

Ibid, s 15.

Ibid, s 16(2).

Ibid, s 16(4).

Ibid, s 52(1).

Ibid, s 13(1).

Ibid, s 54.

Ibid. 
to request the inclusion of a clause that states that expressed warranties and remedies for breach of warranty in the MSA shall be the exclusive warranties that apply to the contract. This type of provision is present in the PSAC Model ${ }^{48}$ and the AIPN/PESA Model. ${ }^{49}$

This approach is favoured by Contractors as they are generally not prepared to offer a warranty of fitness or suitability, but rather are prepared to offer the more limited in scope warranty of compliance with the specifications for the goods identified in the contract. This position arises because the Contractor typically has only the limited knowledge of the well conditions which are provided by the Operator. Consequently, Contractors often take the position that they are providers of services only, and that the goods provided are merely incidental to the services and should not, therefore, be subject to any implied warranties provided by the SGA.

The issue of whether the Contractor is delivering services, or goods and services, can be seen in the case of Burlington Resources Canada Ltd. v. British Columbia. ${ }^{50}$ There, the facts involved the applicability of provincial sales tax (PST) to cementing services and various well stimulation services. The matter arose because the Operator was assessed for PST not paid on materials acquired in the course of procuring services for cementing and well stimulation from the Contractor. The Operator appealed assessment on the basis that the contracts were for services, not for services and the purchase of materials. The Court held that while the Contractor was liable for PST on its cost of materials, no retail sale of materials occurred. This was in part because it found no delivery of materials occurred and that the materials became property of the Operator only after the services were performed. That decision is, however, being appealed by the province. A subsequent decision in Saskatchewan however, Husky Oil Operations Ltd. v. Saskatchewan (Minister of Finance), ${ }^{51}$ also delivered a somewhat contradictory decision; so the debate of provision of services versus goods still appears to be a live one in Canada.

Contractors presumably have expertise in relation to the services that are being provided, and, therefore, Operators typically want to ensure that the Contractor contributes to ensuring that the goods being provided are suitable for the intended application. To do so, Operators must take care to ensure that the specifications for the services contain sufficient detail so as to clearly set out the Operator's expectations for the related goods, or expand the scope of services to engage the Contractor to provide advice on the design for the proposed work operations. Consequently, a Contractor providing only well services will seek to include not just disclaimers of implied warranties related to the goods, but also for any negligent misstatement (or omission) in providing its advice. This is typically done through a general disclaimer clause of any liabilities, regardless of whether it arises under contract, tort, common law, equity, or statute. Without such a disclaimer, a Contractor runs the risk that inaccurate advice could be found to be a negligent misstatement under tort law. This risk could have significant consequences for the Contractor. This is critical as "professional liability" insurance may not be available to the Contractor (as further discussed in Part VIII, below), so corresponding liabilities may fall outside of the coverage of its general 
commercial liability policy. Of note, where a Contractor provides mixed services and sales of goods to the Operator (for example, well services and sale of down-hole tools) the MSA warranty terms are often split into clear and separate warranties: one for services and one for goods. $^{52}$

\section{WARRANTY PERIOD}

After determining the scope of the warranty provided, the next most commonly negotiated warranty issue is the term. The term provided is greatly affected by the bargaining power of the participants as there is no industry consensus on warranty term. For example, the AIPN/PESA Model and LOGIC Model forms allow the participants to insert the number of days they desire for a warranty term. ${ }^{53}$ However, the PSAC Model recommends a 90-day warranty period..$^{54}$ It is the experience of the authors that the range of warranty periods can be as short as to have it expire upon the Contractor's departure from the worksite, or as long as one year from the date of performance of the services. However, most MSA warranty provisions encountered range from expiration upon departure from the worksite to 90 days from the date of performance of the services.

A key issue with warranty term is whether notification of a defect must be received: (1) within the warranty period, (2) within a certain number of days after the expiration of the warranty period, or (3) at any time as long as the defect itself arose within the warranty period. The first example can be seen in the LOGIC Model, ${ }^{55}$ the second in the AIPN/PESA Model. ${ }^{56}$ The PSAC Model is less clear on this issue, as it does not state a time limit within which notification must occur. ${ }^{57}$ From a Contractor's perspective the first and second options add significant certainty regarding its warranty obligations as it can clearly know when its obligations expire.

\section{REMEDIES FOR BREACH OF WARRANTY}

The typical and most likely remedy for a breach of warranty is damages. The equitable remedy of specific performance may also be possible. However, given that Operators can often find replacement services from other contractors, it is unlikely that damages would be found to be an inadequate remedy in the context of a well services scenario. It is common, though, for Contractors to seek to limit the Operator's remedy obligations to the repair, replacement, re-performance, or credit for the defective services. ${ }^{58}$ However, it may be difficult for the Operator to enforce the Contractor's commitment for repair or replacement. If the Contractor does not, for whatever reason, want to repair or replace the services, it can always breach this obligation knowing that damages will be the likely remedy.

Consequently, Operators will typically seek the clear contractual right to procure replacement services at the expense of the Contractor should the Contractor fail in its

See AIPN/PESA Model, supra note 3, ss 7.1.2, 7.1.3.

Ibid, s 7.1.2; LOGIC Model, supra note 4, s 10.2(b).

Supra note 1, s 4.3(b).

Supra note 4, s 10.2(b).

Supra note 3, s 7.1.3.3.

Supra note 1, s 4.3(b).

See ibid, s 4.3(c); AIPN/PESA Model, supra note 3, s 7.1.3.3 (Alternative 1). 
obligation to repair or replace defective services. ${ }^{59} \mathrm{An}$ issue that often arises is the extent of Contractor's liability for repair and replacement costs. For example, Contractor A performs cement work with a contract value of $\$ 100,000$. The work is shown to be defective, and the Contractor refuses to repair the work. The Operator then hires Contractor B, who charges $\$ 140,000$ for the work. A broad indemnity may state that Contractor A is liable for all costs associated with that work (that is, the whole $\$ 140,000$ ). However, if the Operator has refused to pay Contractor A for the defective work (a typical position for defective work), payment of the $\$ 140,000$ by Company A would result in a windfall for the Operator because it got the work done for free. Thus, Contractors usually seek to clarify that their liability for replacement costs is limited to reasonable additional costs (that is, above what would have been payable to the Contractor had they correctly performed the services) and put in place a liability cap for those costs. The cap on liability typically takes the form of a dollar amount, ${ }^{60}$ or a percentage of the amount that would have been payable to the Contractor. ${ }^{61}$

\section{ConSEQuential Loss EXCLUSIONS}

Language excluding liability for consequential or indirect losses are commonly found in MSAs, including the model form agreements. ${ }^{62}$ These paragraphs often start with an overriding statement akin to "notwithstanding anything else in this agreement to the contrary.” Use of this exclusion language should be approached with caution given its ability to affect the negotiated allocation of risk set out in the indemnities section of the MSA, and the potential lack of clarity surrounding what the terms "indirect" and "consequential" include in any particular case. ${ }^{63}$ In any event, there is likely to be debate as to what constitutes "direct" and "indirect" damages. To try to alleviate the problem, the parties will often explicitly list particular types of damages in the exclusion, with loss of profits being one of the most commonly included. However, that type of broad stroke approach to excluding loss of profits may have unintended consequences.

From a Contractor's perspective, defining "loss of profits" to be a type of consequential or indirect damage to which the exclusion applies could have the unintended consequence of excluding the profit margin of the work from the damages recoverable by the Contractor should the Operator fail to make payment for the services. Excluding loss of profits could also limit a Contractor's recovery in other situations where it expects to be compensated. Take for example the tool-rental Contractor who experiences damage or loss to its down-hole tools. While the Operator may have to pay for the direct costs of the damage or loss of the tool, a broad consequential loss disclaimer could mean that the Contractor has an unrecoverable loss in the form of the lost income for that tool during the term the tool is absent from the Contractor's rental fleet.

Further, a party may have an expectation that it will be able to recover consequential or indirect damages where there is a breach of intellectual property or confidentiality obligations in the MSA. Thus, it is important to consider whether these provisions should be

See AIPN/PESA Model, ibid, s 7.1.3.4.

See ibid (Optional Alternative 1).

See ibid (Optional Alternative 2).

See ibid, s 13.3; CAPP/CAODC Model, supra note 2, s 9.15; PSAC Model, supra note 1, s 8.14.

See generally Kangles et al, supra note 11 at 348-50. 
explicitly carved out from any provision that broadly excludes liability for consequential or indirect damages.

\section{INSURANCE}

A fundamental component of the risk management process under the MSA is the insurance provisions. These provide a backstop to the liability and indemnity provisions in the MSA. Therefore, understanding the types of insurance that exist, what each policy covers, what insurance is available to Operators and Contractors, as well as what endorsements should be sought, are critical to understanding the risk allocation underpinning the MSA. However, often little attention is placed on these matters. This is a serious oversight. It can result in a party assuming greater risk than it intended, because either it has assumed a risk that it will be unable to mitigate through insurance, or it has allocated the risk to the other party, but the other party does not have insurance to backstop the obligations which may render the indemnity having little practical value. Furthermore, not fully understanding the endorsements that have been sought or should be sought can result in a party assuming significantly greater risk than was negotiated under the MSA.

\section{A. Typical Insurance Policies}

\section{COMMERCIAL GENERAL LiABILITY (CGL)}

This policy is available to Operators and Contractors. It provides coverage for bodily injury and property damage suffered by third parties for which the insured is liable. It applies to insured liability as a result of law and also to contractual liability stemming from "insured contracts” wherein the insured contractually assumes obligation for liabilities. It typically does not cover losses suffered by third parties as a result of their intentional misconduct and may also exclude losses arising from the third party's gross negligence, and therefore, the indemnifying party under an KK Indemnity will need to rely on its other insurance coverage if the KK Indemnity does not include a carve-out for losses caused by the indemnified party's gross negligence. CGL policies do not cover the insured's pollution liability. However, a pollution endorsement (referred to as "Sudden and Accidental") can be obtained to provide limited pollution coverage, but this coverage will often be subject to multiple exclusions and have low coverage limits. Therefore, as noted below, it is customary for Operators and becoming increasingly common for Contractors to obtain stand-alone coverage for pollution liabilities.

\section{WORKERS’ COMPENSATION / EMPLOYERS’ LIABILITY}

This policy is mandatory for Operators and Contractors. It provides coverage to the insured's employees for bodily injury and protects the employees' families.

\section{PROPERTY COVERAGE}

This policy is available to Operators and Contractors. It provides coverage for damage to the property of the insured. For instance, in the context of a KK indemnity, this policy will provide the insured coverage for the property damage suffered by it and its employees. The policy will also typically cover equipment deemed to be in the care, custody, or control of 
the insured. This can be important coverage for Contractors who may be responsible for equipment supplied by the Operator. It is also important coverage for Operators who may have negotiated the right in the MSA to take control of the Contractor's equipment in response, for example, to a catastrophic event.

The right of the Operator to take control of the Contractor's equipment is becoming more frequent in MSAs. Traditionally, this clause has been limited to drilling contracts and existed so that the Operator could use the rig to drill to regain control of a wild well or drill a relief well. It is more difficult to understand the need for such a clause in an MSA for well services. If the parties agree to include such a clause in the MSA, it is important that the clause clearly establishes that the Operator will, upon taking control of the equipment, have care and custody of the equipment, so as to ensure that damage or loss of the equipment during such circumstances is covered by the Operator's insurance.

\section{CONTRACTORS POLLUTION LiABILITY (CPL) AND POLLUTION LEGAL LIABILITY (PLL)}

This policy is available to Operators and Contractors. It provides coverage for the cost of cleaning up pollution as well as third party claims for bodily injury and property damage arising from the pollution incident. It may also provide limited coverage for pollution fines and penalties. This type of policy is maintained by Operators and large Contractors, whereas many Contractors have traditionally elected to address pollution coverage through an endorsement on their CGL policy. However, an increasing number of smaller Contractors are electing to maintain separate pollution coverage.

\section{WeLl CONTROL (ALSO REFERRED TO AS OPERATORS’ EXTRA EXPENSE (OEE), CONTROL OF WELL (COW), AND BLOWOUT CONTROL)}

This policy is available to Operators. It provides coverage for: (1) the cost to bring the well under control, (2) the cost to re-drill the well, (3) the cost of clean-up resulting from pollution, and (4) third party claims, such as bodily injury and property damage, arising from the well control event. This coverage is not typically available to Contractors. ${ }^{64}$ Therefore, a Contractor should take extreme caution in assuming any responsibility for a wild well event. As noted above, the traditional position under MSAs is for the Contractor to have no responsibility for a wild well or the costs or expenses arising from the incident. However, as further discussed in Part XIV, below, Operators are starting to insist that Contractors assume some liability for wild well events. In such a circumstance, a Contractor may be able to mitigate its risk partially through its pollution coverage, either through a bespoke pollution policy or through an endorsement on its CGL policy. Such policies will not cover the first two categories of loss that an OEE policy will cover, and, thus, if a Contractor is going to accept any liability for a wild well, the triggers for this liability and the limits of its liability need to be carefully drafted so as to minimize the risk exposure to the Contractor's balance sheet.

64 Drilling contractors may procure a contingent well control policy meant to act as a backstop for the Operator's main policy. 


\section{COMMERCiAl AutOMOBiLe, WATERCRAFT, AND AIRCRAFT LIABILITY}

This policy is available to Operators and Contractors. It provides coverage for bodily injury and property damage of persons in the vehicle and third party claims arising from an incident involving the vehicle.

\section{EXCESS/UMBRELLA}

This policy is available to Operators and Contractors. It provides additional liability insurance which can be drawn up after some set amount (or all) of the coverage limit of the primary insurance has been depleted. This is used to top up other liability coverage.

\section{PROFEsSional Liability (Also RefERRED to AS \\ ERRORS AND OMISSIONS INSURANCE (E\&O))}

This coverage is available to certain Contractors. It covers errors made in the design of a project or goods, or in the act or omission in providing professional services. It is intended for engineers and architects and is typically only available to those Contractors that provide design or consulting advice as part of their offered services.

Many MSAs have detailed descriptions of each required coverage. The challenge with this approach is that policies may not fully align with the specifics of such description, albeit they achieve the general intention of the insurance protection being sought. The better approach would be simply to name the sought coverage using customary industry terms, such as those noted above.

\section{B. ENDORSEMENTS TO CONTRACTOR'S INSURANCE}

In order to ensure that the intended protection from an MSA corresponds to the actual coverage afforded by the insurance policies, the party requiring such coverage will want to take steps to ensure that this insurance remains in place for so long as the insured party's indemnity obligations under the MSA apply. This party will also want to maximize the benefit of such insurance coverage and, therefore, will customarily request certain amendments to the insurance policies. These amendments are referred to in the insurance industry as endorsements. The following describes the primary endorsements commonly included in MSAs, explains the reasons for these endorsements, and identifies key issues to be aware of.

\section{AdDITIONAL INSURED (AI)}

This endorsement brings the party named in the endorsement into the insurance coverage. The party is referred to as the "secondary insured" in contrast to the "primary insured" who is the party that obtained the policy. Operators will typically require that the Contractor obtain an endorsement from its insurers for all of the insurance policies that the MSA requires the Contractor to maintain (except for Workers Compensation / Employer's Liability coverage, for which an AI endorsement is not available). The reason for obtaining this endorsement is that the Operator will have a claim directly against the insurer in the event 
of a loss claim that the Contractor has assumed responsibility for under the MSA, rather than having to rely on the contractual indemnities under the MSA.

In preparing the AI language in the typical MSA — which is in regards to the Contractor's insurance - the Operator will want to ensure that the language covers the Operator and its indemnified group, which will typically include the Operator's directors, officers, employees, and agents, as well as the affiliates of the Operator and each of their directors, officers, employees, and agents. It may also include the contractors of the Operator and its affiliates (excluding the Contractor to the MSA). The Contractor will want the clause to be clear that the AI endorsement is limited to the indemnities being provided by the Contractor and is further limited by any exclusions, exemptions, and limitations to which those indemnities are subject. Commonly the qualification language in the AI endorsement clause of the MSA is rather vague, typically stating that the endorsement shall apply to the extent of the Contractor's indemnities and liabilities. If the Contractor is successful in obtaining carve-outs or other limitations to its indemnity obligations, such as a liability cap, minimum claim amounts, or claim limitation periods, it would be prudent to ensure that these are specifically identified in the endorsement.

Despite it being typical practice for an MSA to provide only for an AI endorsement in favour of the Operator in respect of the Contractor's insurance, there is no reason that the Contractor should not also obtain an AI endorsement in respect of the Operator's insurance. While it is typical that some of the Operator's insurance policies will include general wording of coverage to the Operator's contracts under "insured contracts," the potential risk exposure to the Contractor if a wild well event occurs makes it prudent to take steps to ensure that they have such an endorsement. Think of the massive liability claims which arose as a result of the Macondo blowout against the drilling contractor (Transocean Offshore Deepwater Drilling Inc. (Transocean)), the cement provider (Halliburton), and the manufacturer of the blowout preventer (Cameron International). This is also of particular importance to those Contractors providing pressure pumping services in connection with large-scale hydraulic fracture operations, particularly when being provided to smaller Operators, due to the significant capital of the Contractor that is represented on-site during the performance of this type of well service operation.

If the AI endorsement clause is not drafted sufficiently broad, the party to the MSA that is the beneficiary of the endorsement runs the risk of not being able to make a direct claim against the counterparty's insurance. Conversely, if the AI endorsement clause is not drafted to limit the endorsement to the counterparty's indemnity obligations, the secondary insured may have the right to obtain broader coverage under the policy than was intended. Additionally, a perfectly drafted endorsement clause in a MSA still does not achieve the desired goal if the endorsement is not actually obtained from the insurer. Hence it is important for the beneficiary of the endorsement to ensure that the endorsement is attached to and forms part of the main policy, or that confirmation is obtained that the policy has automatic AI wording that provides the beneficiary the desired secondary insured coverage.

Typically, the indemnity clauses in the MSA are in a different section than the insurance clauses. While it is common to include a clause in either the indemnity or the insurance section that expressly states that the indemnity provisions are not limited by the scope or coverage of the insurance policies that the indemnitor is required to maintain, cautious parties 
will want to ensure that wording is also included in the indemnity clauses that references the additional insured clause.

An ongoing US case acutely identifies the risk attenuated by AI endorsements. In $R e$ Deepwater Horizon $^{65}$ a US court was asked to consider whether BP American Production Company (BP), which had entered into a drilling contract with a predecessor entity of Transocean in order to exploit the Macondo well, was entitled to make a claim under Transocean's umbrella insurance policy for costs incurred by BP in connection with the pollution resulting from blow-out. The subject policies provide US $\$ 750$ million of coverage.

The drilling contract included customary terms whereby Transocean was required to maintain insurance covering its operations under the contract, and that BP and its affiliated companies "be named as additional insureds in each of [Transocean's] policies, except Worker's Compensation for liabilities assumed by [Transocean] under the terms of this Contract."66 The contract further provided that Transocean would indemnify BP for liability for pollution "originating on or above the surface of the land or water." ${ }^{67}$ Transocean did not assume liability for spills originating below the surface of the water. An AI endorsement had been issued by the underwriter of Transocean's umbrella insurance policy. After the spill, BP pursued additional insurance coverage under policies issued to Transocean, including BP's subsurface pollution liability. Transocean's underwriters sought declaratory judgment that they owed no additional insured obligation to BP with respect to pollution claims pertaining to pollution originating below the surface of water. The insurers argued that their additional insured obligation was limited to liabilities assumed by Transocean under the drilling contract.

The trial court adopted the approach that MSA negotiators anticipated: the AI endorsement provided BP access to Transocean's insurance only so far as the liabilities assumed by Transocean under the contract. Since Transocean did not assume liabilities for spills originating below the surface of water, the AI endorsement did not provide coverage to BP for liabilities arising from the blowout. However, the Fifth Circuit reversed this decision, holding that even if the drilling contract specifies that BP is to be "an additional insured under Transocean's policies only for liabilities Transocean specifically assumed in the Drilling Contract ... we are bound to look only to the policy itself to determine whether BP is covered in the current case."68 The Court further explained that the "case law makes clear to us that only the ... policy itself may establish limits upon the extent to which an additional insured is covered," and the policy language in Transocean's policies "imposes no relevant limitations upon the extent to which BP is covered." ${ }^{69}$ As a result, BP would be entitled to access Transocean's insurance policies pertaining to claims relating to pollution originating under the surface of the water.

The Fifth Circuit panel has subsequently withdrawn its decision and asked the Texas Supreme Court to weigh in. ${ }^{70}$ This was due to the Fifth Circuit concluding that there are 
potentially important distinctions between the facts of the case and the relied-upon case law. The Texas Supreme Court has not yet heard the case. This case is sure to be followed closely in the US and in the broader international oil and gas industry.

While the ultimate results of this case remain uncertain and will not be binding in Canada, it is prudent to be aware of this decision since the sheer magnitude of the dollars involved have drawn the attention of MSA draftspersons from around the world, as well as the attention of the global insurance industry. As a consequence, practices are being modified in the drafting of the MSA indemnity clauses and in the wording of the AI endorsements. These will no doubt find their way into the Canadian marketplace.

To mitigate the risks attenuated by an AI endorsement:

- the parties should ensure that the relevant MSA clause addresses the aspects noted above regarding (1) clearly identifying the additional insured, and (2) describing the scope and limitations of the AI coverage, for example, listing the indemnities to which it applies and any limitations or restrictions on the indemnities such as claim limits and claim thresholds;

- the endorsement granted by the insurer needs to mirror the language from the endorsement clause in the MSA;

- the indemnity and AI provisions of the MSA should refer to each other;

- the additional insured needs to obtain confirmation that the insurer has attached the endorsement to the policy; and

- the AI endorsement should clearly establish whether it is the secondary or the primary insured who is responsible for paying the claim deductible in the event that the secondary insured makes a claim under the policy.

\section{CROSS LIABILITY}

The party that has obtained the AI endorsement should also seek an endorsement that the insurance policy includes a cross liability provision. In the event of a claim by one insured party against another insured party covered by the same policy, this endorsement provides that the insurance policy will respond as if separate policies had been issued to each insured party. Without this clause, a party runs the risk that, by being endorsed as an AI, its ability to recover under the insurance may be limited, at least in respect of claims that will be indemnified by the other insured party for which it seeks recourse for under the same insurance policy. This is because under common law a person cannot sue him or herself, and because of an AI endorsement the policy would cover both the Contractor and the Operator. Many insurance policies will contain such provisions. Hence, this request should not be a contentious issue. However, because of the significant adverse consequences if the policy does not include this provision, it is prudent for the additional insured party to make this a requirement in the insurance provisions of the MSA. 


\section{WAIVER OF SUBROGATION}

Obtaining this endorsement is of paramount importance if the MSA includes a risk allocation whereby a party may be liable to the counterparty for losses suffered by the counterparty (whether direct losses or losses arising from third party claims) that are caused by the counterparty or its indemnity group. Without the waiver, the indemnified party could recover indemnity compensation under the MSA and then need to defend itself against a counterclaim by the indemnifying party's insurer for the recovery of some (or all) of the compensation, if the indemnifying party had sought coverage under its insurance policy for the compensation paid to the indemnified party. From a Contractor's perspective, having your insurer turn around and sue your customer would not be an ideal conclusion to the incident.

Obtaining the waiver from the insurer ensures that the insurer is aware that it will be losing its subrogation rights. This is a beneficial assurance since many insurance policies prohibit the insured from prejudicing the insurer's rights of subrogation. Thus, by obtaining the endorsement from the insurer, the endorsement recipient can be assured that the waiver has not compromised the coverage it is relying upon to backstop the indemnities granted in its favour under the MSA. The subrogation waiver should be sought from all of the counterparties' insurance, with the exception of workers' compensation and the employer's liability policy. Also, automobile insurance may be excluded, depending on the wording, since such endorsements are not available for these policies in Canada.

Typically, only the Contractor is obligated to obtain the subrogation waiver from its insurers. Broadly speaking, this practice has developed because the Operators are typically larger companies, and thus their insurance acting as a backstop to their indemnity obligations is perceived to be less critical. Also, the events which are likely to trigger the Operator's insurance are instances of catastrophe (for example, a wild well), and the insurance policies providing coverage for this type of event customarily provides coverage for losses suffered by the Operator's contractors. However, considering the increasing costs of wells and the limited financial resources of many Operators in the current capital-constrained environment, as well as the increased environmental monitoring, it is reasonable for Contractors to adopt a more rigorous approach to ensuring that the Operator's insurance will be there to provide coverage in the event of a claim by the Contractor.

Another approach to mitigating the risk of the insurer's subrogation rights is to obtain a release from the insured party. Since the insurer steps into the shoes of the Contractor when making a subrogated claim, the subrogation rights of the insurer can be usurped by including in the MSA a release by the Contractor in favor of the Operator. The release should be broadly worded so as to have the Contractor release any and all rights to claim against the Operator or its indemnity group whether under contract, tort, statue, or other branch of law or equity for any claims, losses, expenses, and costs that the Contractor suffered or incurred to the extent that they relate to matters which the Contractor has agreed to indemnify the Operator and its indemnity group.

Despite the benefit of including a release in the MSA, it is rarely found in the language. However, it is prudent to obtain both the release and waiver. This protects against the risk 
of any issues with the wording of the waiver which may compromise its effectiveness and the risk of the waiver not being obtained.

\section{PRIMARY AND NON-CONTRIBUTORY ENDORSEMENTS}

Two endorsements that supplement the AI endorsement that should be requested, but which are often not, are "primary insured" and "non-contributory" endorsements. These endorsements ensure that the applicable insurance policy pays out the claim to the maximum of the loss amount and the coverage limit without regard to any other insurance the additional insurer may maintain. It is only after this insurance coverage is depleted that an additional insured then needs to seek contribution from any insurance it separately maintains. These endorsements simplify the claim reimbursement process, since the various applicable insurers do not need to agree upon apportionment of responsibility for the claim, and reduces the likelihood of the additional insured from having to draw upon the insurance for which it is the primary insurer.

\section{Protecting The InSURANCE Benefits}

The insurance coverage is only valuable so long as it is in place. Thus, it is common in MSAs to include a requirement that the party maintaining the insurance is obligated to provide the other party with prior notice of cancellation of a policy. This party should also be obligated to seek an endorsement from its insurers to provide prior notice of cancellation of an insurance policy. These requirements provide an effective monitoring process to confirm that the policies remain in place. However, it is important to note that the parties may only be able to obtain confirmation that the primary insured will "endeavour to" provide notice of cancellation to the additional insured, since insurers in Canada often will only guarantee notice of cancellation to named insureds. ${ }^{71}$

A related clause that frequently appears in MSAs is the requirement to obtain an endorsement for the insurer to provide prior notice to the additional insured of any material changes to the policy. While the benefits of such an endorsement are obvious, this endorsement is not customarily provided by Canadian insurers since the insurers do not want to be in a role of determining what is material. Therefore, such endorsement requirements should not be included in the MSA. If a party insists on its inclusion, then it should be worded carefully so that the obligation of the party who is to seek the endorsement is to "request" the endorsement, rather than to "obtain" the endorsement.

If an additional insured is particularly concerned with ensuring that the other party's insurance package remains in place, then it should: (1) specify in the MSA that the insurance must remain in place, regardless of termination of the MSA, until the end of the period in which a claim for indemnification under the MSA can be made; and (2) that if any of the required policies are materially changed or cancelled that the additional insured is entitled to procure alternative coverage, with the costs of doing so being the responsibility of the

71 If an AI endorsement is obtained, the insurer will, as a matter of the terms of the insurance policy, have to provide the same notice to the secondary insured as it provides to the primary insured. However, this obligation of the insured is only in respect of "named" insured, and thus if the policy has an automatic AI endorsement, notice will not be provided by the insurer unless a separate requirement is obtained. 
indemnifying party. The latter approach is rare in MSAs but common in upstream joint venture agreements, such as joint operating agreements, so it should be a concept that is familiar to most MSA negotiators.

The additional insured should also seek to obtain a copy of the indemnifying party's insurance policies and all endorsements. Frequently parties merely require a certificate of insurance. This is not ideal. The certificate is for informational purposes only and does not typically establish a legal obligation from the insurer to the additional insured. Moreover, the certificate merely provides a summary of the insurance and will not typically describe the exclusions and limitations that may exist in the policy. Even if it does provide a summary of the requirements, exclusions, and exemptions, there can be important variances in the specific wording of these clauses from policy to policy. Cognizant that undertaking all of these steps can represent a significant administrative hurdle, each party should assess the relative importance of each policy required under that MSA in the context of the risks anticipated under the MSA, to determine what level of review and monitoring a party should undertake.

\section{SUBCONTRACTORS}

Operator-orientated MSAs may include the requirement for the Contractor to ensure that its subcontractors maintain insurance that is materially the same as that which the Contractor is required under the MSA to maintain. There are two concerns with this requirement. The first is the practical challenge of the Contractor ensuring that its subcontractors have insurance policies that are materially the same as that required under the MSA. A second concern is that the Operator is satisfied with the insurance coverage in the absence of any subcontracting by the Contractor, so the involvement of subcontractors should not change this. It is an internal matter for the Contractor to determine if it wants to ensure that the subcontractors' insurance aligns with the MSA obligations such that the Contractor can pass liability to the subcontractor. If the Operator is concerned that the participation of subcontractors introduces additional risk, this concern is more efficiently addressed through adjusting the liability cap and requiring the Contractor to increase its insurance coverage. However, it is important that in making this determination the Operator keep in mind the commercial implications this change may have to the rates under the MSA versus the implications of the Operator having to potentially draw upon its own insurance as a result of the liability cap or the Contractor's insurance coverage being exceeded.

\section{InTEllectual Property}

\section{A. IsSUES WITH IP PROVISIONS}

With technology being a key differentiator in the marketplace, provisions governing ownership and licensing of intellectual property (IP) rights are commonplace in modern MSAs. Contractors take the position that unless a scope of work specifically contemplates the development of IP for the ownership of the Operator, it is the Contractor that should own any developed IP. Operators, on the other hand, should be concerned with ensuring that they are given sufficient IP rights associated with the services to allow them to use the services as contemplated. Common issues with IP provisions in MSAs include inappropriate 
allocation of ownership of developments, overly broad licensing or assignment of rights, and overreaching non-infringement and indemnification obligations.

\section{AlLOCATION OF IP Rights}

If a Contractor is merely attending to a site to perform a service and leave, an MSA that provides that the Operator owns any IP developments made by the Contractor (even to its own processes) is likely overreaching. A balanced starting point for allocation of IP rights for a simple provision of services arrangement can be seen in the PSAC Model, whereby:

The Operator and the Contractor agree that:

a) all Intellectual Property originated by the Contractor prior to entering into this Master Service Agreement and all Intellectual Property developed solely by the Contractor during the term of this Master Service Agreement or any particular Services Work Order shall belong to the Contractor;

b) all Intellectual Property originated by the Operator prior to entering into this Master Service Agreement and all Intellectual Property developed solely by the Operator during the term of this Master Service Agreement or any particular Services Work Order shall belong to the Operator; and

c) if the Operator and the Contractor jointly develop any Intellectual Property associated with the Services, they shall negotiate in good faith and execute a development agreement to identify and allocate ownership rights in the jointly developed Intellectual Property. ${ }^{72}$

A similar allocation to the above is also seen with the LOGIC Model. ${ }^{73}$ However, in the case where the Contractor has been specifically contracted to develop processes, technology, or other IP for the Operator, this allocation would not be effective, and the Operator's ownership stake in the IP rights will need to be clearly set out.

\section{ASSIGNMENT VERSUS LiCENCE}

A further issue when allocating IP rights is the difference between an assignment and a licence. Assignments are the conveyance, sale, and transfer of the IP interest and title, whereas with a licence there is no transfer of any interest or title in the IP; there is merely a contractual permission to use and exploit the licensor's IP. Contractors should be careful to avoid assigning their IP rights where a mere licence is intended so as not to lose the benefits of ownership of their IP, and potentially their right to use it.

\section{EXTENT OF IP LICENSING}

If a party is providing a licence to use its IP, it is important to define the extent of that licence, as licences are conditional upon the licensee conforming to the terms of the licence given. Thus, a Contractor risks overly broad and uncompensated use of its IP with an overly broad licence. An Operator, on the other hand, should not be prevented from making its 
intended use of the goods or services by an overly restrictive licence grant. Therefore, the following should be considered when drafting the licence:

- the description of the IP being licenced;

- whether it is an exclusive, non-exclusive, or sole licence;

- duration of the licence;

- whether the licence can be sub-licensed to others;

- the field of use allowed by the licence (for example, an industry-specific or productspecific use); and

- geographic restrictions on use (for example, worldwide licence versus province- or region-specific).

Of particular note to Contractors is the difference between exclusive, sole, and nonexclusive licences. In an exclusive licence, the licensor gives the licensee the exclusive right to make use of the particular IP to the exclusion of all others, including the licensor. This is the most restrictive licence grant and can be similar in effect to an IP assignment. A sole licence on the other hand similarly prevents the licensor from licensing the IP to any other licensees, but unlike the exclusive licence still allows the licensor to make use of the licensed IP. Non-exclusive licences, as the phrase suggests, grants the licensee the right to use the IP but still allows the licensor to grant licences for the same IP to other licensees.

\section{EXTENT OF INFRINGEMENT INDEMNIFICATION}

With the provision of IP comes the potential for intellectual property infringement and litigation. Problems can arise in a variety of ways including breaches of underlying contracts or licences, patent infringement, trademark infringement, or copyright infringement, and the problems do not require intent on the part of the infringing party. It is typically the position of the Operator that the Contractor should bear the risks arising from the provision of Contractor IP, as it is the Contractor that has greater control over such issues, with the Operator having little or no control. Consequently, Operators often insist upon IP warranties and a corresponding indemnity from the Contractor.

The Contractor should, however, seek to limit its obligation to indemnify the Operator or licensees where the Operator has modified the IP and issues arise from that modification, and where the Operator used the IP for an unintended purpose. This type of carve-out to the indemnification obligation can be seen in the AIPN/PESA Model. ${ }^{74}$ Alternatively, or in conjunction with such indemnity limitation, the Contractor may seek to lessen the scope of the IP warranty to say only that the Contractor has not knowingly infringed upon any licence or patent. This limited warranty is the approach found in the PSAC Model. ${ }^{75}$ Ultimately, because there is no constant industry practice with regard to IP obligations, the extent of the IP warranties and indemnities will be a matter of negotiation between the parties. 


\section{Compliance With Human Resources and HSE Policies}

While safety in the workplace continues to be at the forefront of most Operators and Contractors, there does not appear to be a consistent approach to the issue of compliance with health, safety, and environmental (HSE) practices. In the experience of the authors there seem to be three primary approaches to HSE compliance: (1) the Contractor is required to create and abide by its own existing HSE policies, with the Operator often setting certain minimum requirements; (2) the Contractor is required to comply with the Operator's HSE policies; and (3) the creation of a custom, work-specific, HSE policy or the use of bridging documents to ensure the applicable HSE policy is acceptable to the Operator. The second approach appears to be by far the most common starting point in Operator-drafted MSAs, and it is the approach taken by the AIPN/PESA Model. ${ }^{76}$ However, that approach can be problematic as the Operator's HSE policies are usually written with a view to its normal operations, and not the specific services being performed by the Contractor. Conversely, Contractor policies are typically written in contemplation of the specific services being provided. Thus, compliance with Operator HSE policies may not be applicable or may suffer from ambiguity when used for the services. On the other hand, the use of custom plans, or the more recently seen use of HSE bridging documents, can have significant benefits. There the Operator and Contractor must turn their minds to the applicable policies and how they operate in light of the services to be performed, which helps to ensure relevant policies and compliance mechanisms are in place. The PSAC Model and CAPP/CAODC Model contemplate almost identical requirements for Contractor compliance with good oilfield industry practices. Any additional written policies or specifications that are provided to the Contractor are agreed to by the Operator and the Contractor. ${ }^{77}$ The LOGIC Model specifically contemplates the use of HSE bridging documents (referred to as interface agreements). ${ }^{78}$

\section{REQUIRED HOLDBACK UNDER THE BUILDERS’ LIEN ACT}

An item to be aware of when preparing the payment provisions of an MSA are the holdback requirements under builders' lien legislation. ${ }^{79}$ Broadly, builders' lien legislation requires that all persons who make payments under a contract or subcontract in a construction chain retain a holdback related to the value of the work actually done and materials actually furnished for a period of time. In addition to this amount, the owner is also required to retain during any time while a lien is registered, any amount payable that has not been paid under the contract that is over and above the holdback. ${ }^{80}$ It is not possible to contract out of the provisions of this legislation. ${ }^{81}$

The holdback is the owner's protection from liens. If the owner properly maintains the holdback, it can pay the holdback into court to remove the lien, regardless of whether the holdback is sufficient to satisfy the lien. In the absence of obtaining and properly maintaining

Supra note 3, s 21.6.2, Schedule 4.

PSAC Model, supra note 1, 4.1; CAPP/CAODC Model, supra note 2, s 4.1.

Supra note 4, s 32.2 .

See e.g. Builders' Lien Act, RSA 2000, c B-7, s 26 [BLA, (Alta)]; Builders Lien Act, SBC 1997, c 45, ss 4-9; The Builders' Lien Act, SS 1984-85-86, c B-7.1, ss 34-48.

See e.g. BLA, (Alta), ibid, s 18(2).

See e.g. ibid, s 5. 
the holdback, the owner would have to pay the lienholder the full amount protected by the lien in order to avoid the risk of the unpaid subcontractor seeking to enforce its right to foreclose on the land or minerals. As a consequence, if an Operator fails to retain the holdback amount, it runs the risk of having to pay the amount of the lien twice: once to the Contractor and once to the lienholder, such as a subcontractor of the Contractor. The Operator will then have to attempt to seek recovery from the Contractor under the MSA provisions.

It is rare for an MSA to grant the Operator the right to withhold a portion of payments due under the MSA in contemplation of complying with this statutory requirement. The common argument raised against the Operator holdback payment is that the MSA will customarily include a requirement for the Contractor not to permit its subcontractors to file liens against the property where the work is being performed, and further provides an exemption to the full payment obligation of the Operator to allow the Operator to settle any liens filed by the Contractor's subcontractor and set-off such amount from payments due under the MSA or otherwise seek reimbursement from the Contractor. Considering the value of work performed by subcontractors under a typical MSA, as compared to the financial capacity of major Contractors, this approach reflects a reasonable commercial practice. However, for Operators procuring services from small Contractors or in relation to MSAs where significant portions of work will be performed by subcontractors, it would be prudent for an Operator to think twice before accepting the typical approach.

\section{CANAdian JURISPRUDENCE}

Considering the significant number of MSAs that exist in the Canadian oil and gas industry, there is surprisingly little judicial consideration of the provisions of an MSA. In fact, of the few cases that do exist, almost all pertain to drilling contracts. While the absence of jurisprudence could be interpreted as indicating a high degree of consensus in the industry as to the meaning of the typical provisions in an MSA, it is more likely the case — and is the experience of the authors — that disagreements are customarily resolved through commercial solutions so as to avoid the significant time, cost, and uncertainty of a court process and avoid damaging the commercial relationships of the involved parties.

The following are some important Canadian cases to be aware of, and the key points of law considered that are relevant to MSAs. There is also a body of tax cases pertaining to well services, ${ }^{82}$ and while many of them provide a helpful factual summary of well services and MSAs, the issues in such cases deal with the application of taxation to the services provided, and thus are beyond the scope of this article.

\section{A. HoRIZON RESOURCE MANAGEMENT LTD. V. BLAZE ENERGY LTD. ${ }^{83}$}

Blaze is a recent Alberta Court of Appeal decision. The main action of this case was a claim by Roll'n Oilfield Industries Ltd. (Roll'n), a drilling company, for payment owed by Blaze Energy Ltd. (Blaze) under an MSA that was based on the CAPP/CAODC Model form 
MSA. To earn a working interest in future production from a shut-in sour gas well, Blaze was required to drill a new well in a short time period. Blaze hired Roll'n to drill the well. The well was not completed after seven weeks and, therefore, Blaze released Roll'n. As a consequence, Roll'n commenced an action seeking payment for the work performed. Blaze counterclaimed for damages. The main findings held by the trial judge (and affirmed on appeal) in relation to negotiating MSAs were:

- The entire agreement clause foreclosed the possibility of any claim for pre-contractual misrepresentations. The Court found that the entire agreement clause also did not have to explicitly exclude liability in tort to exclude an action in negligence. This boilerplate clause was the essential determinative factor in this decision.

- The decision stresses the importance of including (or referencing) any documents relevant to the services. The Court held that because of the entire agreement clause, a drilling program which was not appended to the contract did not form part of the contract, and acting contrary to the program did not breach the contract. This same reason can be easily extended to work programs under MSAs for well services.

This case is also a useful summary of the finding of previous courts in regards to exclusion clauses, gross negligence, and the priority of the indemnity clauses.

\section{B. BRINKERHOFF INTERNATIONAL INC. V. NUMAC ENERGY INC. ${ }^{84}$}

Brinkerhoff International Inc. (Brinkerhoff) was providing drilling services to Numac Energy Inc. (Numac). The services were governed by the 1993 version of the CAPP/CAODC Model. During the drilling of a well, a blowout occurred, and a fire ensued and destroyed Brinkerhoff's drilling rig. Brinkerhoff claimed indemnity for the physical damage to the drilling rig and the resulting economic loss from the loss of use of the rig. The parties sought direction from the court regarding the construction of the liability and indemnity provisions in the drilling contract.

The contract included a risk allocation similar to that frequently found in MSAs, including a "surface equipment" clause whereby the Contractor assumes liability for its equipment (except for specific exemptions). It included a "wild well" clause whereby the Operator is liable regardless of fault or negligence for the cost of controlling any blowout as well as the cost of removal of any debris. Further, the Operator was to indemnify the Contractor from any and all losses, damages, and so on, thereby suffered or incurred by the Contractor. The "surface equipment" clause did not include the "wild well” clause as a specific exemption.

Brinkerhoff argued that the "wild well" clause was intended to supersede the "surface equipment" clause in the specific circumstances of a wild well, and thus Numac was responsible to indemnify Brinkerhoff for the damage to the rig and its resulting economic loss from the loss of the use of the rig. Numac argued that the indemnity in the "wild well" clause was limited to the costs incurred in connection with controlling the wild well and the 
cost of removing any debris resulting from the wild well. The trial judge held that the "wild well" clause applied to the Contractor's equipment (including the rig) in the context of a wild well, whereas the "surface equipment" clause applied to the Contractor's equipment (including the rig) in other situations only. Pursuant to the indemnity in the "wild well" clause, Numac was responsible for the cost of the rig, but the contract was ambiguous regarding economic loss. ${ }^{85}$

The Court of Appeal overturned the trial decision and held that the "surface equipment" clause applied in all instances, including for loss of the Contractor's equipment arising from a well blowout. In regards to economic loss, the Court of Appeal held that neither clause addressed economic loss. Therefore, in the absence of any specific limitations language otherwise in the contract, the general "fault-based" provisions would apply. Thus, Brinkerhoff would be responsible for the economic loss it suffered as a result of the loss of the rig.

The takeaways from this case in the context of preparing an MSA, are as follows:

- If the intention of the parties is for loss or damage to the Contractor's equipment arising from a well blowout to be covered by the Operator, then care should be taken to include the "wild well" clause as a specific exemption to the "surface equipment" clause. While this risk allocation may vary depending on the type of well services being provided, the specific circumstances of the work and the relative bargaining power of the parties, it is desirable for this risk allocation to be clearly understood so that the party assuming the risk can take the appropriate steps to manage its risk (such as ensuring adequate insurance coverage), and for the party not assuming this risk to reduce the likelihood of having to undertake litigation to enforce its contractual protections.

- The magnitude of these potential losses makes it prudent for the parties to identify clearly in what (if any) circumstances a party's indemnity obligations under the MSA are intended to cover the economic loss of the other party. It would also be prudent to supplement this approach by including in the MSA a clause whereby each party expressly disclaims liability for the economic loss of the other party except as expressly provided for in the MSA.

\section{BUILDERS’ LIENS}

There is a body of case law dealing with the validity of builders' liens filed in connection with drilling services, the most recent of which is Arthur Andersen Inc. v. Artisan Corp. ${ }^{86}$ These cases generally affirm the contractual constructive principle that is customarily included in MSAs: the MSA and each work order and service order issued thereunder constitute a single contract and, therefore, enable the Contractor to file a general lien where any (or all) of the lien amount could be applied against any of the properties that the lien was filed against. 


\section{Caution When Using Model Agreements}

A degree of comfort can be taken that the Canadian-based PSAC model agreement was prepared by people familiar with the Canadian legal and business environment and that the wording was crafted in contemplation of these circumstances. However, as in all instances of using a precedent, care needs to be taken to ensure that the wording accurately addresses the specific operational circumstances and expectations of the parties. An even more cautious approach is advisable when using a non-Canadian based model form agreement or wording from such agreements, since those were prepared in contemplation of an operating environment and legal system which can have important differences. An English case provides a salient example for applying this caution.

In Seadrill Management Services Ltd. v. OAO Gazprom, ${ }^{87}$ Gazprom and Seadrill entered into a drilling contract using the IADC International Offshore Daywork Drilling Contract. Under the contract, Seadrill agreed to provide Gazprom with a jack-up rig to drill a well. During pre-loading, the rig was damaged and had to be towed and repaired. The parties elected to have the contract governed by English law. As noted above, the IADC is prepared by the US-based IADC. A key issue in the case was whether the drilling contract excluded liability for the Contractor, Seadrill, for damage to the rig and resulting damages suffered by Gazprom. At the trial level, Seadrill introduced expert evidence that the intention of the person preparing the model form, as affirmed by US courts, was that the Contractor is exempt from such liability. Nonetheless, the trial judge held that: (1) Seadrill had acted negligently, (2) that this negligence was the sole cause of the incident during pre-loading, (3) the drilling contract did not exclude liability for such negligence, and (4) Seadrill was liable for losses suffered by Gazprom as a result of the incident. Seadrill appealed this decision, and the Court of Appeal upheld the judgment.

The clauses at the centre of the dispute read as follows:

501. Contractor ... assumes only the obligations and liabilities stated herein. Except for such obligations and liabilities specifically assumed by Contractor, Operator shall be solely responsible and assumes liability for all consequences of operations by both parties ... notwithstanding ... the negligence or fault of Contractor.

911....the provisions of [certain clauses] shall exclusively govern the allocation of risks and liabilities of said parties without regard to cause. ${ }^{88}$

Seadrill argued that the contract apportioned risk between the parties such that neither party was liable to the other except as expressly provided for in the contract. Construction of the contract, particularly paragraph 501, put the risk of all incidents on Gazprom, except for those incidents where the contract specifically allocated a risk to Seadrill. Seadrill had not specifically assumed liability for negligent pre-loading of the rig under the indemnities set out in the paragraphs referenced above, so it was not liable for Gazprom's losses. In 
addition, Seadrill had not specifically assumed the obligation to exercise reasonable care and skill, and such an obligation could not be implied from the contract. Even if there was such an implied obligation, it did not carry with it any liability if Seadrill failed to perform that obligation to the required standard. Gazprom argued that conventional principles of English law applied. Despite the lack of an express standard of performance in the contract, English law implied an obligation on Seadrill to perform services with reasonable skill and care. Seadrill breached this implied standard of performance. Furthermore, the scope of the exclusions on liability in the contract did not exclude Seadrill's liability for breach of this implied term.

The trial judge held that:

- American authorities on the interpretation of the form of contract are of little importance and cannot be used to subvert the normal English law principles of construction.

- There must be clear words in a contract before a court will hold that the contract has taken away rights or remedies which a party would otherwise have at common law (the judge found that paragraph 911 of the contract did not clearly and unequivocally amount to an exclusive code of risk allocation).

- Paragraph 501 also failed to clearly and unequivocally exclude Seadrill's obligation to operate the rig with reasonable skill and care. Seadrill assumed an obligation to operate the rig and, as a matter of English law, a necessary incident of that obligation was that Seadrill would operate the rig with reasonable skill and care. ${ }^{89}$

The Court of Appeal added these additional comments:

- Paragraph 501's reference to obligations and liabilities specifically assumed by Seadrill should be taken to refer not only to obligations arising out of the express terms of the contract, but also to "all the incidents which the law ordinarily attaches to them," unless there was clear evidence of an express agreement to the contrary. ${ }^{90}$

- Had the parties intended to allocate the risk of loss and damage without regard to these obligations, they would have been made clear in the contract that the purpose of specifying their obligations was merely to identify their respective roles. ${ }^{91}$

Both courts suggested that a carefully worded "waiver of implied duties" clause coupled with a broadly-worded expression of exclusive liability clause may have been sufficient to provide Seadrill the protection that it surely assumed that it had when it entered into the contract. The Alberta Court of Appeal decision in Blaze $e^{92}$ suggests that Canadian courts may take a less strict approach to this issue. However, because of the significant negative impact

Seadrill (trial), supra note 87 at paras 173, 182, 186.

Seadrill (appeal), supra note 87 at para 28.

Ibid at para 20.

Supra note 83. 
to a Contractor of an adverse ruling, it would be prudent to take extra care in drafting explicit liability exclusionary clauses.

\section{RECENT TRENDS AND OPEN ISSUES}

\section{A. Contractor Liability for Subsurface Pollution}

A trend that has gained momentum after the Macondo blowout is the requirement for the Contractor to assume partial responsibility for the risk of subsurface pollution. As noted above, the customary practice is for the Contractor to have no responsibility for subsurface pollution. While this position has historically been accepted by Operators, Operators are starting to push back and require their supply chain also to be responsible for major pollution events. The rationale for this approach is that it will incentivize service providers to perform their role with greater care and attention.

While this area continues to emerge (it cannot be said that any new standard has been established or that there are even any typical or common approaches), some approaches that the authors have seen are: (1) the Contractor is liable for a determined amount of liability arising from the subsurface pollution; and (2) the Contractor is liable for subsurface pollution that is caused by its gross negligence or wilful misconduct, subject to a maximum liability. It remains to be seen how common this risk allocation approach becomes, but considering the increasing regulatory scrutiny, it is likely that such provisions will become more common.

\section{B. CONTRACTORS MODIFYING KNOCK-FOR-KNOCK IndeMnities in Regards to PREssure PuMPING SERVices}

Pressure pumping services require a significant amount of Contractor equipment. This equipment is expensive, running in the tens of millions of dollars. As a result, Contractors are starting to revisit the appeal of a pure KK Indemnity in regard to their surface equipment. While this trend will likely not move quickly, it is a trend that can be expected to gain momentum so as to align better the risk and reward of these services. Approaches that the authors have seen in this regard are similar to the current trend regarding subsurface pollution control but in reverse. Namely, the Contractor KK Indemnity will apply up to a threshold amount, and then the Operator will assume responsibility for the damage to the Contractor's equipment in excess of this threshold amount.

\section{DOES A BREACH OF DUTY OF CARE INVALIDATE THE INDEMNITIES?}

An area of uncertainty is whether a breach of the MSA, such as a breach by the Contractor of its standard of care, invalidates the indemnities under the MSA This has not been determined in Canada. It remains an open issue in the US and the UK, with courts in both jurisdictions having acknowledged that a scenario could arise whereby a breach of a fundamental or core obligation of the MSA could invalidate the indemnity provisions. ${ }^{93}$ The 
basis for this position is that otherwise the standards under the MSA would be mere declarations of intention rather than binding obligations. ${ }^{94}$

It would, therefore, be prudent for Contractors to expressly address this matter in the MSA. Presumably this could be done by identifying that the limitations on the scope of liability of the Contractor is not abrogated by a breach by the Contractor's standard of care, if one is stated in the MSA. Alternatively, from the Operator's perspective, the Seadrill case suggests that being silent on this matter may be advantageous. ${ }^{95}$ 